Литвиненко Світлана

доктор педагогічних наук, професор, професор кафедри практичної психології і психотерапії Рівненського державного гуманітарного університету https: orcid.org/0000-0002-7736-2152

Ямницький Вадим

доктор психологічних наук, професор, професор кафедри практичної психології і психотерапії Рівненського державного гуманітарного університету https: //orcid.org/0000-0002-1741-1303

DOI https://doi.org/10.35619/praprv.v1i16.226

\title{
КОНЦЕПТУАЛЬНІ ЗАСАДИ СУЧАСНОГО РОЗВИТКУ СИМВОЛДРАМИ
}

\begin{abstract}
Анотація. $У$ статті висвітлено конщептуальні засади сучасного розвитку кататимно-імагінативної психотерапії (символдрами), зумовлені зверненням у теоріі $i$ практиці роботи у методі не тільки до дослідження інтерсуб'єктивної парадигми та кататимних імагінацій як структурованої техніки $i$ терапевтичного засобу, але й до значущзості терапевтичних стосунків як чинника терапевтичних змін. 3 'ясовано, щзо сучасні автори більш глибоко $і$ виважено звертаються до вивчення образного досвіду, який розгортається в імагінаціях пацієнта, з позиції відображення динаміки терапевтичних стосунків, а необхідною умовою забезпечення повноти переживання імагінативного процесу визнають побудову надійної та безпечної психотерапевтичної взаємодії. У руслі сучасних підходів розвитку методу символдрами виокремлено й обгрунтовано терапевтичні функиії імагінацій та символів.
\end{abstract}

Ключові слова: психотерапія, символдрама, імагінація, терапевтичні стосунки, центральна тема конфліктних стосунків, символ, терапевтичні функцї імагінацій та символу.

Постановка проблеми. Символдрама - сучасний напрям психодинамічної, глибинно орієнтованої психотерапії, у якому використовується робота 3 уявою («сновидіннями наяву»). Появі методу як самостійного напряму сучасної психотерапії передувала тривала клінічна та дослідницька робота німецького психотерапевта, доктора медицини, професора Ханскарла Льойнера (Hanscarl Leuner, 2005). У практичному вжитку набули популярності різні назви методу: символдрама (Symboldrama), кататимно-імагінативна психотерапія (КІП), кататимне переживання образів (КПО), метод «сновидінь наяву», а в англомовному просторі - «Guided Affective Imagery» (скеровані афективні образи). Метафорично символдраму називають «психоаналізом за допомогою образів», що відображає сутність, розробленого Льойнером, методу з використанням кататимних імагінацій (у формі супроводжуваного сновидіння наяву), які завдяки своїм образним, афективним та символічним якостям виступають своєрідним спонуканням для виникнення «декорацій» на уявній образній сцені.

У ході дослідницької роботи та клінічної практики Льойнер (1954 - 1985 рр.) розробив терапевтично-методичні кроки, форми супроводу і підтримки імагінативного процесу та започаткував метод кататимного переживання образів (КПО). Імагінації почали використовуватися як структурована техніка i центральний терапевтичний засіб. Концептуальні засади методу складають глибинно-психологічні теорії, що визначають дослідження особливостей особистісного розвитку пацієнтів (генетичні глибинні форми несвідомих конфліктів, афективно-інстинктивних імпульсів, процесів і механізмів захисту тощо) та зумовлюють основи психотерапевтичної практики (формування альянсу, збір анамнезу, встановлення показань й обгрунтування цілей терапії, робота 3 перенесенням i 
контрперенесенням, несвідомими конфліктами і порушеннями особистості тощо); а також екзістенційно-аналітичний метод (Льойнер, 1996; Leuner, 2005).

Аналіз останніх досліджень 3 проблеми. Новаторські підходи й відкриття Льойнера знайшли подальний розвиток у доробках сучасних авторів (Барке, Нор, 2019; Хайгл-Эверс, Хайгл, Отт, Рюгер, 2001; Жиловська, Обухов-Козаровицький; Турецька, 2001; Хенінг, 2008; Ульман, 2020). Поряд із зміною фокусу сучасного психоаналізу 3 дослідження інтрапсихічного світу пацієнтів до інтерсуб'єктивної парадигми у теоретичних пошуках і практиці роботи учні та послідовники Льойнера звернулися не лише до дослідження особливостей роботи 3 кататимними імагінацями, але й до значущості терапевтичних стосунків як чинника терапевтичних змін.

Метою статті виступило висвітлення концептуальних засад сучасного розвитку кататимно-імагінативної психотерапії (символдрами), виокремлення й обгрунтування терапевтичних функцій імагінацій та символів.

Виклад основного матеріалу дослідження. Центральна тема конфліктних стосунків (ЦТКС), згідно Люборскі, може виявлятися на рівні внутрішнього конфлікту та в актуальній системі взаємодії (Хенінг, 2008). У зв'язку з цим виявлення й опрацювання ЦТКС у ході терапії зумовлює фокусування й зосередження на трьох сферах життя пацієнтів: дитячі стосунки, актуальні найближчі стосунки, терапевтичні стосунки. У КІП додається ще й четверта - сфера символічної «сцени» супроводжуваного сновидіння наяву, що дозволяє не тільки «зазирнути всередину» трьох згаданих сфер, але й пережити альтернативний досвід і новий розвиток подій (Ульман, 2020). У роботі 3 імагінаціями дослідник визнає сприятливими анаклітичні (тобто такі, на які можна покладатися) і водночас діалогічні (співпрацюючі й довірливі) стосунки. Таку діалогічну взаємодію у КІП терапії порівнює зі своєрідною театралізацією, імпровізовановаю імагінативною сценою, на якій відбувається щось особливе й унікальне, коли сновидець наяву та терапевт втілюють різні ролі (режисерів, акторів, глядачів), а у діаді терапевт-пацієнт відбувається спільне творення «чогось третього». Активовані в імагінативному досвіді епізоди, постають ніби в іншому контексті, що дозволяє їх більш повно пережити й опрацювати у ході терапевтичної роботи завдяки пошуку нових смислів і творенню нових наративів. До цього додається новий досвід стосунків «тут i тепер», який може бути інтегрований пацієнтом на символічному i нейронному рівнях.

У таких стосунках пацієнт як «сновидець наяву» спонтанно та завдяки спонуканню терапевта одночасно постає у різних суб'єктно-об'єктних позиціях й ділиться з терапевтом пережитим афективно забарвленим досвідом. Тому фокус терапевтичної роботи, на думку Ульмана, може коливатися між двома полюсами, один з яких - конфлікт між бажаннями i перешкодами, що опрацьовується шляхом конфронтації та інтерпретації (згідно концепції «імпульсу» i «захисту» у класичній психоаналітично орієнтованій терапії неврозів). Водночас поряд 3 «експліцитними» техніками існують також «імпліцитні», пов'язані 3 несвідомими мотивами пацієнта, що дозволяє відкривати простір для нового розвитку. Внаслідок цього ЦТКС виростає до «центральної історії стосунків» (ЦІС), у якій кататимне переживання образів окреслює бачення одужання і програє його так, ніби в реальному житті (Ульман, 2020).

Процес КІП, згідно Ульмана, постає метафорично-наративним, оскільки в терапевтичному діалозі народжуються інтерактивні метафори, в яких концентруються центральні теми психотерапії, що слугують орієнтирами у виборі мотивів. Усе, що генерується як символ у сновидінні наяву, набуває метафоричних якостей у подальшому перебігу КІП і переходить у площину інтерактивної метафори в терапевтичному діалозі, у якому концентруються центральні теми терапії. Тобто, символічний зміст імагінацій набуває форми метафор в обговоренні, оскільки середовищем метафори є слово. У зв'язку з цим Ульман зауважує, що багато з того, що представлене у підручнику Льойнера з КПО, як робота з символами і над символами, насправді є терапією за допомогою метафор (Ульман, 2020). 
У загальному вигляді склалися відмінності щодо принципів та цільових аспектів міжсуб'єктної терапевтичної взаємодії та імпліцитних, неінтерпретативних факторів терапевтичного процесу. На думку окремих авторів (Барке, Нор, 2019), створений Льойнером навчальний посібник, недостатньо повно відображає сучасний рівень психодинамічної самосвідомості психотерапевтів, що передусім стосується розуміння терапевтичного ефекту методу. Так, з позиції засновника символдрами терапевтичний ефект пов'язується 3 імагінативною силою символічних процесів задля вивільнення матеріалу конфлікту (Льойнер, 1996), а не з терапевтичними стосунками. У зв'язку з чим перенесенню $\mathrm{i}$ контрперенесенню, які формуються у стосунках терапевт-пацієнт, надавалася більш підпорядкована роль. Хоча основоположник символдрами й усвідомлював значимість терапевтичних стосунків і динаміки перенесення, проте вважав дане знання «обов'язковим» для КІП-терапевтів на «середньому і вищому щаблях» підготовки. Така позиція Льойнера заклала дещо спрощене бачення терапевтичних функцій методу, особливо на тлі проблем негативного перенесення, яке може виникати й програватися на «полотні імагінацій» та утримуватися протягом тривалого часу або ж виключатися 3 терапевтичного процесу. Слід зауважити, що вибір терапевтом для пацієнтів стандартного мотиву чи асоціативного занурення в імагінацію засновується на його внутрішній гіпотезі чи інтуїтивній фантазії, актуалізованій у певних терапевтичних ситуаціях. Сама пропозиція імагінації з мотивом або без нього тією чи іншою мірою $є$ символічним відображенням контрперенесення психотерапевта.

Відтак, у сучасній концептуалізації (Барке, Нор, 2019; Ульман, 2020; Хенінг, 2008 та ін.) збережена основоположна сутність методу, що полягає у кататимній імагінації у формі супроводжувального сновидіння наяву, яке може розгортатися у всій повноті лише у межах сприятливих для цього стосунків. У такій взаємодії пацієнт постає «сновидцем наяву» й ділиться пережитим досвідом з усіма можливими відтінками думок, почуттів і бажань, а терапевт - надійним партнером у діалозі та гарантом безпеки у розгортанні символдраматичної сцени. На відміну від Льойнера, сучасні автори більш глибоко i виважено звертаються до спостереження й розуміння образного досвіду, що розгортається в імагінаціях пацієнта як відображення динаміки терапевтичних стосунків, а необхідною умовою забезпечення повноти переживання імагінативного процесу визнають побудову надійних та безпечних терапевтичних стосунків.

У руслі сучасних підходів розвитку методу символдрами (Барке, Нор, 2019 та ін.) визначено провідні терапевтичні функції імагінацій, як-от: вираження $i$ прояснення; стабілізації; формуюча структуру функція. Схарактеризуємо згадані функції більш докладно.

У терапевтичній роботі функція вираження $i$ прояснення визначається здатністю імагінацій до прояву внутрішніх психічних станів і конфліктів. Так, на «внутрішньому екрані» пацієнтів у символічно-образній формі оживають бажання й виявляються захисні механізми, а також особливості прояву сили Я і саморегуляції. Такий процес імагінативного відображення несвідомого матеріалу постає проміжним кроком у сходженні до вербалізації й обговорення отриманого в образі досвіду, а також слугує матеріалом для спонтанних інсайтів і нових можливих ракурсів усвідомлення та рефлексії. Відтак, символічно-образний досвід забезпечує на імагінативному рівні певну конфронтацію з самим собою й надає можливість креативного пошуку рішення проблеми у формі уявного пробної дії або ж дозволяє відчувати не прожиті аспекти себе й обробляти обмежувальні імпульси Над-Я.

Функція стабілізації у терапевтичній роботі зумовлена «Я-підсилюючою» підтримкою регресії (регресія на службі власного Я) у проживанні імагінативних образів, а також повнотою їх переживання. Наприклад, завдяки релаксації й зниженню рівня тривоги або ж активації завдяки імагінації внутрішніх ресурсів. Так, згідно, Льойнера простежується певний цикл: імагінації зумовлюють розслаблення, яке сприяє «виразності образів уяви», а це, у свою чергу, може підсилювати розслаблення (Льойнер, 1996). Водночас зауважимо, що подібна циклічність залежить від структурного рівня організації особистості пацієнта, а також стосунків у перенесенні. 
Крім того, функція стабілізації пов'язана 3 символічною компенсацією відсутнього емоційного досвіду, що досягається завдяки зануренню у «сновидіння наяву» 3 усією повнотою почуттів, відчуттів, рухів і дій. Так, на думку Льойнера, у ході психотерапевтичної роботи з імагінаціями наповнюються і зазнають терапевтичних змін нарцисичні дефіцити (Балінт, Кохут та ін.). На початкових етапах у пацієнтів 3 обмеженою здатністю до символізації можуть виникати труднощі у роботі зі сновидіннями наяву та при входженні у терапевтичні стосунки. Однак, зорієнтований на побудову безпечних, надійних та довірливих терапевтичних стосунків процес КІП, забезпечує поступове й бережне дозрівання здатності до символізації. Стабілізуючим може бути й перехід від бесіди до імагінації, оскільки розширює можливості регулювання дистанції й афекту в психотерапевтичному процесі. Зворотній перехід від «сновидіння наяву» до подальшого опрацювання забезпечує можливість керованої регресії Тим самим, поєднання у КІП психотерапії завдяки імагінаціям конфронтаційної роботи й стабілізації забезпечує зниження тривоги, пом'якшення й вирішення конфліктів.

Формуюча структуру функизія імагінацій дещо відрізняється, хоча й взаємозв'язана 3 попередніми функціями. Вона спрямована на подолання розщеплення, зміцнення самості й розвиток саморегуляції, що сприяє забезпеченю інтеграції особистісних структур і більш реалістичному сприйняттю себе й об’єктів. В імагінативному просторі переживань у процесі психотерапії з опорою на холдинг і контейнерування активуються підтримуючі репрезентації себе і об'єкта (наприклад, в образах допомагаючих персонажів і ресурсних місць тощо), що сприяє зміцненню системи самості або часткового подолання розщеплення за допомогою певних технік інтервенцій. Так, у пацієнтів 3 порушенням структурної організації, які страждають від страхів фрагментованості, за допомогою спонукання до позитивних підтримуючих символічних персонажів може бути ініційована увага й турбота про потреби дефіцитарних частин самості; у випадках роботи з розладами металізації кататимна імагінація поєднує афективний, чуттєвий та тілесний досвід і водночас звертається до вербалізації пережитого. Крім того, імагінації та їх додаткове оформлення у малюнках постають як перехідний об’єкт (Барке, Нор, 2019; Ульман, 2020 та ін.), що забезпечує підтримку цілісності й константності переживання об'єкта під час перерв у психотерапії, а також полегшує сепарацію з психотерапевтом під час закінчення психотерапевтичного курсу.

Відзначимо, що робота із образною символікою актуалізує різні продуктивні психічні процеси (переживання, рефлексія, прогнозування, відреагування, інтеграцію, структурування тощо), а символ у психотерапії опосередковує процеси смислового перетворення свідомості пацієнта (усвідомлення / породження / утвердження смислів). Обгрунтування значущості символу у сучасному вимірі різних психотерапевтичних модальностей і шкіл (Василюк, Льойнер, Менегетті, Мінделл, Фром, Хьонінг, Цибуля, Юнг та ін.), функції якого визначаються вихідними теоретичними позиціями щодо чинників детермінації психологічних проблем і засобів досягнення цілей психотерапії, дозволяє збагатити та розширити концептуальні та прикладні аспекти КІП.

Узагальнюючі сучасні наукові підходи (Барке, 2019; Льойнер, 1996; Нор, 2019; Цибуля, 2012 та ін.), схарактеризуємо більш докладно провідні терапевтичні функції символу, які реалізуються у ході психотерапевтичної роботи за методом символдрами.

1. Усвідомлення смислу симптому або проблемної ситуації. У ході психотерапії зміст даної функції символу виявляється в усвідомленні пацієнтом внутрішнього смислового зв'язку симптому з переживаннями певних подій. Це відбувається, коли у свідомості пацієнта відтворюються його особистісна історія та встановлюється змістова відповідність між симптомом чи травматичною подією у минулому, а також пов'язаними з цим досвідом витісненими почуттями й думками.

Реалізація у ході психотерапії такої функції символу передбачає дотримання певних умов, зокрема: терапевт припускає, що симптом або проблема пацієнта, а також особливості взаємодії терапевта і пацієнта у ході терапевтичної сесії втілюють прихований, терапевтично значущий, психологічний смисл; терапевт використовує прийоми інтерпретації для 
осмислення симптомів пацієнта і особливостей його поведінки; пацієнт приймає значення, які пропонує йому терапевт для осмислення його симптому або проблеми.

2. Смислотворення як терапевтична функція символу полягає у тому, що завдяки використанню певних мотивів, прийомів і технік символдрами (наприклад, мотив «Мудрий старець», діалог із значущими фігурами в асоціативному методі, діалог 3 «симптомом» та образами сновидінь, робота з малюнками тощо) пацієнт відкриває або переживає значущий для нього смисл, який змінює його сприйняття й усвідомлення проблемної ситуації i ставлення до неї. Творення смислу відбувається завдяки слідуванню за розгортанням символічних образів імагінацій та їх ампліфікацією у ході обговорення. Символ виступає як певна цілісність, смисловий центр, що обіймає багатство глибинних смислів. Тим самим завдяки діалогу пацієнта 3 образною символікою символічний образ постає не як застигла структура $з$ прихованим змістом, а як живий організм, який саморозвивається і розгортає свої смислові аспекти у ході певних терапевтичних процедур (малювання, діалог, ампліфікація тощо). При цьому терапевт заохочує й підтримує пацієнта та фасилітує його самостійний творчий пошук.

3. Функція породження та ескалації переживань зумовлена особливостями імагінативного досвіду пацієнта через проживання ним образів і символічних сюжетів. Зміст функції реалізується завдяки кінестетично-чуттєвій формі і семантиці образної символіки, яка надає певної глибини та якості переживанням пацієнта. Експлікація переживань в образній символіці імагінацій відкриває можливості для самодослідження і самопізнання, оскільки переживання має терапевтично значущий продуктивний сенс, який може бути глибше усвідомлений. Творення символічних образів і подальша робота щодо їх розуміння й усвідомлення сприяють самопізнанню та особистісному розвитку. Образи і символи втілюють значущі почуття і стосунки пацієнта, які проживаються й набувають особистісного сенсу, що забезпечує продуктивну динаміку та якісну зміну переживань пацієнта, пов'язаних з його труднощами та проблемами. У ході психотерапії завдяки ампліфікації, розуміння й осмислення символу, властивостей і характеристик його зовнішньої форми звертаються до прояснення й розкриття смислового змісту буття пацієнта. Тим самим у свідомості пацієнта формується осмислена особистісна історія, яка характеризує його буття у світі.

4. Відреагування як функція символу полягає у тому, що пацієнт у безпечному терапевтичному просторі за допомогою символічних засобів виражає витіснені переживання і нереалізовані емоційні реакції. Відмінність цієї функції від попередньої полягає у можливостях вияву пацієнтом у символічній формі витіснених і табуйованих почуттів та утвердженні його права на витіснені почуття і переживання.

5.Функція інтеграції реалізується завдяки творчому самовияву пацієнта через образи і малюнки у поєднанні повноти проживання ним імагінативного досвіду та осягнення й розуміння втілених у символі неусвідомлюваних бажань, почуттів і суперечливих складових змісту його життєвого досвіду, що забезпечує становлення смислової цілісності внутрішнього світу пацієнта.

6.Організація простору i часу терапії, формування особливого ставлення до терапевтичного процесу є універсальною функцією, властивою для різних модальностей психотерапії. Ця функцію втілена у символічних ролях пацієнта і психотерапевта та спеціальним чином організованому просторі, символічних ритуалах $\mathrm{i}$ атрибутах психотерапії, що забезпечують відповідне «налаштування» пацієнта на процес терапії. Наприклад, кушетка, як символ психоаналізу, формує специфічне ставлення до психотерапевтичного процесу і моделює зміст відносин пацієнт-психотерапевт; а також процедура оплати терапевтичних сеансів, яка крім прагматичного значення набуває й символічного сенсу (Цибуля, 2012).

7. Прогнозування як терапевтична функція символу відображає смислову закономірність динаміки психічного життя пацієнта. Зміст функції полягає у тому, що завдяки символу розкриваються діагностичні виміри, провідні тенденції та перспективні напрями розвитку пацієнта на шляху індивідуації (наприклад, символічне значення ініціального мотиву «Квітка», ландшафтна символіка у мотивах основного ступеня тощо). 
8. Структурування психічних процесів. У психотерапії за методом символдрами зазначена функція реалізується у тому, що запропоновані Льойнером для уявлення образи або символічні сюжети (наприклад, ландшафтні та інші стандартні мотиви) слугують певними «формами» для організації продуктивного психічного досвіду пацієнта. Зміст функції полягає у тому, що відповідно глибинних смислів символу задається структура i напрям роботи переживань пацієнта, пов'язаних з його внутрішніми конфліктами.

Висновки i перспективи подальших розвідок. Отже, у сучасних вимірах символдрами дослідники звертаються до вивчення діалогічної, стосункової взаємодії, завдяки чому для пацієнта у ході терапевтичного процесу відкриваються сприятливі можливості для проживання й рефлексії його несвідомих конфліктних відношень до об'єктів, їх ранніх передумов та актуальних проявів, що, у свою чергу, забезпечує можливості для нового корегуючого емоційного досвіду й змін поведінкових та когнітивних стереотипів. Використання символу як психотерапевтичного засобу забезпечує глибину афективного проживання й «вихід» у простір пошуку альтернативних смислів і значень, що приводить пацієнта до переосмислення своїх конфліктів і проблеми, а також породжує значимий, співбуттєвий досвід терапевтичних стосунків.

Незважаючи на те, що багато сучасних публікацій набули практичної спрямованості і висвітлюють лише окремі аспекти методу, проте символдрама має грунтовні інтегративні засади, які надають особливої цілісності кататимній імагінації. Водночас усі елементи, інтегровані у метод КІП органічно поєднуються 3 іншими підходами та техніками психотерапії, зберігаючи при цьому власну унікальність й автентичність. Терапевти інших напрямів і терапевтичних шкіл знаходять шляхи оволодіння та можливості використання методу «сновидіння наяву» у власній практиці роботи.

\section{СПИСОК ПОСИЛАНЬ}

Лейнер, Х. (1996). Кататимное переживание образов: Основная ступень. Москва: Эйдос.

Хенинг, Х. (2008). Об имагинативном измерении аналитической психотерапии. СПб.: ООО

Издательский дом Офсет-мастер.

Ульман, Г. (2020). Вступ до кататимно-імагінативної психотерапії. Жовква: Місіонер.

Барке, У., Нор, К. (2019). Кататимно-имагинативная психотерапия. Москва: Когито-Центр. Турецька, X. I. (2017). Фактори ефективності імагінативних технік психотерапії. Науковий вісник Херсонського державного університету. Серія: Психологічні науки. Вип. 4. Том 2, 187-192.

Хайгл-Эверс, А., Хайгл, Ф., Отт Ю., Рюгер, У. (2001). Базисное руководство по психотерапии. СПб: «Речь».

Цыбуля В.И. (2012). Функции символа в психотерапии. Консультативная психология и психотерапия, 2, 158-173.

Hanscarl Leuner (2005) Katathym-imaginative Psychotherapie (KiP). Hrsg., Fortgeführt von Eberhard Wilke. Georg Thieme Verlag KG, Stuttgart 2005, 6. Auflage.

\section{REFERENCES}

Leyner, H. (1996). Katatimnoe perezhivanie obrazov: Osnovnaya stupen [Guided Affective Imagery: Main stage] M.: Eydos. [in Russian].

Hening, H. (2008). Ob imaginativnom izmerenii analiticheskoy psihoterapii [About the Guided Affective Imagery of analytical psychotherapy] SPb.: OOO Izdatelskiy dom Ofset-master. [in Russian].

Ulman, G. (2020). Vstup do katatimno-ImagInativnoYi psihoterapIYi [Introduction to Guided Affective Imagery] Zhovkva: MIsIoner. [in Ukrainian].

Barke, U., Nor, K. (2019). Katatimno-imaginativnaya psihoterapiya [Guided Affective Imagery]. M.: Kogito-Tsentr. [in Ukrainian].

Turetska, H. I. (2017). Faktori efektivnostI ImagInativnih tehnIk psihoterapIYi [Factors anderlying the effectiveness of the imaginative techniques of psychotherapy]. Naukoviy vIsnik 
Hersonskogo derzhavnogo unIversitetu. Serlya: PsihologIchnI nauki. 2, 187-192. [in Ukrainian].

Haygl-Evers, A., Haygl, F., Ott Yu., Ryuger, U. (2001). U. Bazisnoe rukovodstvo po psihoterapii. [Base guidance on psychotherapy] SPb: «Rech». [in Russian].

Tsyibulya V.I. (2012). Funktsii simvola v psihoterapii. [Functions of symbol are in psychotherapy]

Konsultativnaya psihologiya i psihoterapiya, 2, 158-173. [in Russian].

Hanscarl Leuner (2005): Katathym-imaginative Psychotherapie (KiP). Hrsg., Fortgeführt von

Eberhard Wilke. Georg Thieme Verlag KG, Stuttgart 2005, 6. Auflage.

\title{
CONCEPTUAL FUNDAMENTALS OF MODERN DEVELOPMENT OF GUIDED AFFECTIVE IMAGERY (SYMBOLDRAMA)
}

Svitlana Lytvynenko

Professor of the Department of Practical Psychology and Psychotherapy Rivne State University of Humanities https://orcid.org/0000-0002-7736-2152

Vadim Yamnitsky

Professor of the Department of Practical Psychology and Psychotherapy Rivne State University of Humanities https://orcid.org/0000-0002-1741-1303

DOI https://doi.org/10.35619/praprv.v1i16.226

\begin{abstract}
The article covers the conceptual foundations of modern development of Guided Affective imagery (Symboldrama) based on theory and practice of the therapeutic method, the study of intersubjective paradigm and katatimny imaginations as the structured technique, therapeutic tool, but also to the importance therapeutic relationships as a factor of therapeutic change. The article defined that modern authors have a deeper and more balanced approach to the study of imaginative experience. Experience which unfolds in the patient's imagination, from the perspective of reflecting the dynamics of therapeutic relationships and consider building a reliable and safe therapeutic relationship.

In line with modern approaches to the development of the method of Guided Affective Imagery, the therapeutic functions of imaginations and symbols are distinguished and substantiated. It is noted that work with imaginary symbolism actualizes various productive mental processes (experience, reflection, prediction, reaction, integration, structuring, etc.), and the symbol in psychotherapy mediates the processes of semantic transformation of the patient's consciousness (awareness / generation / affirmation of meanings). Proving the significance of the symbol in the modern dimension of various psychotherapeutic modalities and schools on the factors determining the psychological problems and means of achieving the goals of psychotherapy, allows to enrich and expand the conceptual and applied aspects of Guided Affective Imagery.

Key words: psychotherapy, guided affective imagery (symboldrama), imagination, therapeutic relations, central theme of conflict relations, symbol, therapeutic functions of imaginations and symbol.
\end{abstract}

